\title{
A non-native macroalga is less attractive for herbivores but more susceptible to light limitation and grazing stress than a comparable native species
}

\author{
Patrício Ramalhosa ${ }^{1,2^{*}} \mathbb{D}$, Sarah-Lena Debus ${ }^{3,4}$, Manfred Kaufmann $n^{2,5,6}$ and Mark Lenz ${ }^{7}$
}

\begin{abstract}
It has been suggested that non-native species are more tolerant towards abiotic stress than ecologically comparable native species. Furthermore, non-native marine macroalgae should be under lower grazing pressure than native seaweeds, because they left their co-evolved enemies behind. As a consequence, they generally need to allocate less energy to defences and can invest more into compensating the negative effects of abiotic stress or, assuming that grazing pressure is low but not zero, to defensive reactions following grazer attack. This, in turn, should make them more stress tolerant and less susceptible to herbivory. However, empirical evidence for both concepts is still scarce and very little is known about whether enemy release is commonly associated with an enhanced tolerance towards abiotic or biotic stress. We therefore ran an experimental study that (a) assessed attractiveness for grazers, (b) verified whether short-term low-light stress impairs growth and (c) investigated whether light limitation and previous grazing interactively affect the consumption of two macroalgae from Madeira Island, the native brown alga Stypopodium zonale and the non-native red alga Grateloupia imbricata by the sea urchin Paracentrotus lividus. To come to ecologically meaningful low-light stress levels, pilot studies were performed in order to determine the light compensation point of photosynthesis for each algal species and then we established six light regimes around this point by reducing the amount of incoming light. Simultaneously, we let one sea urchin graze on each algal individual to stimulate a chemical defence in the seaweeds if present. In parallel to this, we kept the same number of algal replicates in the absence of sea urchins. After 21 days, we compared algal growth in the absence of grazers as well as the attractiveness of previously grazed and non-grazed algal material for $P$. lividus across all light regimes. Algal attractiveness was assessed in no-choice feeding assays. The observation that the non-native alga was less consumed by the grazer than the native species generally confirms the concept of enemy release. However, light limitation reduced growth in the non-native but not in the native seaweed, while previous grazing reduced consumption of the native but enhanced it in case of the non-native alga. These findings do not corroborate the assumption that enemy release can, through the re-allocation of energy, enhance tolerance to abiotic (light limitation) or biotic (grazing) stressors in non-native marine macroalgae.
\end{abstract}

Keywords: Bioinvasions, Light deficiency, Grazing, Anti-herbivore defences, Grateloupia imbricata, Stypopodium zonale, Paracentrotus lividus

\footnotetext{
*Correspondence: patramalhosa@gmail.com

1 Present Address: MARE - Marine and Environmental Sciences Centre,

Quinta do Lorde Marina, Sítio da Piedade, 9200-044 Caniçal, Madeira

Island, Portugal

Full list of author information is available at the end of the article
} 


\section{Background}

Biological invasions are considered to be one of the greatest threats to marine biodiversity $[1,2]$. One of the most fundamental questions in terrestrial as well as in aquatic invasion ecology is which factors determine the invasion success of introduced species [3]. In this context, tolerance to adverse environmental conditions is viewed as an important pre-requisite for invasion success and it is a widely accepted notion that non-native species are more robust $[4,5]$. Several empirical studies that considered abiotic stressors such as temperature [6], wave action [7], light limitation [8], salinity fluctuations [9] and oxygen concentration [10] actually found that non-native organisms commonly have a higher tolerance than ecologically similar and/or taxonomically related native species. So far, most studies on the effects of environmental stress have focused on the physiological responses of single organisms to adverse conditions [11], but did not consider the consequences of stress for biotic interactions [12]. Another widely discussed driver of biological invasions is the release of introduced species from biotic pressures, e.g. predation and competition, in the recipient region [13 and references therein]. The enemy release hypothesis (ERH) suggests that non-native species should experience low predation/grazing pressure, because they left their co-evolved enemies behind and because native antagonists fail to recognize them as a potential food source [14]. This concept has repeatedly been tested for herbivore-plant interactions in terrestrial [15] as well as in aquatic systems [16]. Colautti, Ricciardi [17], in a literature review, identified 25 studies that tested various aspects of the ERH and $60 \%$ of these investigations generally supported the concept. Hence, the picture is not unambiguous and it is still doubtful whether the ERH is of universal relevance for plant species which have been introduced to regions from which they were previously absent [18]. Another implicit prediction of the ERH is that individuals, which are generally released from biotic pressures such as predation or herbivory, need to invest less energy into defences against their enemies [19]. In turn, this energy should then be available for other life processes such as growth and reproduction, but also for the compensation of abiotic stress or for defensive reactions following an attack. The re-allocation of energy following enemy release could, at least partly, explain the enhanced tolerance towards stress in non-native species. This connection between enemy release and stress tolerance has not been investigated and we lack empirical studies that verify whether enemy release is commonly associated with enhanced stress tolerance in the affected species.

In coastal regions, macroalgae are important primary producers that often form complex and diverse habitats which provide nursing grounds and food for numerous benthic and pelagic organisms [20]. Moreover, macroalgal species belong to those organisms that are frequently introduced to habitats from which they were previously absent [21]. This mainly results from their transport as target or non-target species for aquaculture purposes [22]. Williams and Smith [23] estimate a global number of 277 introduced seaweed species of which 165 are rhodophytes (red algae), 66 are phaeophytes (brown algae), and 45 are chlorophytes (green algae) as well as 1 charophyte. Macroalgae therefore make up a considerable proportion of the number of biological invasions in costal habitats, representing about $10-40 \%$ of the total nonnative species worldwide [19].

The distribution and abundance of resident macroalgae as well as the invasion success of introduced species is to a large extent controlled by marine meso- and macrograzers [24]. These consumers belong to different taxa, are of very different sizes and exhibit various feeding modes. Generalist herbivores such as sea urchins are among the largest of these grazers and can, if not controlled by antagonists, modify the structure of benthic communities by transforming erect algal communities into barren grounds [25].

However, macroalgae evolved different strategies to reduce the consequences of herbivore attack by preventing or reducing consumption through structural and chemical defences [26]. The latter are widespread in all groups of seaweeds and they are based on secondary metabolites, which lower consumption rates by reducing algal palatability or even intoxicate the enemies [27]. Chemical deterrents can be permanently expressed (constitutive chemical defences) or temporarily produced in response to grazing pressure (induced chemical defences) [28]. Production of secondary metabolites on demand (i.e. increase in metabolite synthesis following grazing pressure) has been described in many studies on green [29], brown [30] and red algae [31].

Although defences against herbivory have been described for many marine macroalgae, little is known about their metabolic costs and whether energy limitation, e.g. by a shortage in light available for photosynthesis, impairs the formation of anti-herbivory structures or compounds [32]. However, if defences are costly in terms of metabolic energy resource limitation should result in a reduced defence capacity and this should, in turn, lead to an increase in tissue palatability and therefore herbivore consumption. Despite the fact that temporary light limitation is a likely stressor for macroalgae in coastal waters [33], which can be due to the enhanced growth of planktonic algae and epiphytes as well as to the import of particles through river run-off or the re-suspension of sediments, its consequences for algal defences have rarely 
been investigated in an experimental approach [34, but see 35].

In this study, we conducted an indoor experiment on Madeira Island in which we investigated whether attractiveness for the sea urchin Paracentrotus lividus [36] differs between the native brown alga Stypopodium zonale [37] and the non-native red alga Grateloupia imbricata [38]. This was done to test the predictions of the ERH. Furthermore, we verified whether short-term low-light stress impairs growth in the two alga species to check for differences in robustness towards abiotic stress. Finally, we assessed whether light limitation and previous herbivory separately or interactively affect grazer consumption rates. So far, nothing has been reported about defences in G. imbricata, while $S$. zonale is known to have a constitutive resistance against several grazer species [39].

\section{Methods}

\section{Study site and organisms}

This study was done on Madeira, a volcanic island $\left(32^{\circ} 38^{\prime} \mathrm{N}, 16^{\circ} 54^{\prime} \mathrm{W}\right)$ located southwest of continental Europe in the subtropical North Atlantic (Fig. 1a). All experiments described here were conducted from June to September 2007 using the indoor laboratory facilities at Estação de Biologia Marinha do Funchal (EBMF) located at the south coast of Madeira (Fig. 1b, c).

The organisms used for this study were the sea urchin Paracentrotus lividus, the red seaweed Grateloupia imbricata and the brown seaweed Stypopodium zonale. The sea urchins were collected from rocks in water depths of $2-5 \mathrm{~m}$ at Doca do Cavacas, Funchal $\left(32^{\circ}\right.$ $38^{\prime} 06 \mathrm{~N} ; 16^{\circ} 56^{\prime} 52 \mathrm{~W}$ ) (Fig. 1c, d). Paracentrotus lividus inhabits intertidal rock pools as well as the subtidal down to $20 \mathrm{~m}$. At exposed sites, the urchin commonly hides in natural crevices or in cavities that it burrows into the rock [40]. We identified P. lividus as the most suitable macrograzer for our experiments, because it is abundant in the system, it readily feeds on macroalgae and can be found on natural and artificial substrata. Grateloupia imbricata was collected from the marina of Funchal $\left(32^{\circ} 38^{\prime} 41 \mathrm{~N}\right.$; $\left.16^{\circ} 54^{\prime} 46 \mathrm{~W}\right)$, where it was highly abundant on pontoon bridges at $0.5 \mathrm{~m}$ water depth (Fig. 1c, e). This alga has red to brown cartilaginous fronds, occurs in dense tufts and is native in Japan and Korea [41]. It was first observed on Madeira in 2005 [42], when individuals were found growing attached to pontoons in Funchal harbour, while for the Canary Islands it was first described in 2007 [43], when individuals were observed in rock pools in the upper and lower intertidal. This Asian species has, for the first time, recently been reported for continental Europe, when it was found in the marina of Gijón, Bay of Biscay,
Spain. The earlier reports from Madeira and the Canary Islands therefore suggest a ship-mediated stepping-stone route from its native range in the Pacific into Europe [43, 44]. Stypopodium zonale is a native species in Madeira Island and we collected it from boulders at Reis Magos, Caniço $\left(32^{\circ} 83^{\prime} 45 \mathrm{~N} ; 1^{\circ} 49^{\prime} 25 \mathrm{~W}\right)$ in water depths of 3-7 m (Fig. 1c, f). Stypopodium zonale is known to have a constitutive resistance against several grazer species [45]. This algae has thick blades, which are heavily corticated [46]. It is abundant in the tropical Pacific and Atlantic oceans and can be found in water depths from 0.2 to $81 \mathrm{~m}$ [47]. Although the two seaweed species belong to different taxonomic groups, they are of similar size as well as growth form and both thrive in oligotrophic waters along subtropical and tropical coasts.

During collection, all algae were carefully detached from their substratum by hand during apnoea, leaving the algal holdfast undamaged. All organisms were transported to the laboratory within $1 \mathrm{~h}$ inside containers filled with seawater. After arrival, the algae were cleaned from epibionts as well as associated invertebrates and were then stored in aerated aquaria. We acclimatized them for 7 days in the laboratory to minimize potential effects of previous herbivory. During this time, the algae received light from fluorescent lamps, which were also used in the experiments (see below). Sea urchins were collected from the field and acclimatized to laboratory conditions for 3 days prior to the stress experiment as well as prior to the feeding assays. During this time, they were kept in large tanks with air supply and were fed with a mixed diet of freshly collected S. zonale, G. imbricata, Ulva lactuca and Padina pavonica. This diet was offered during the acclimatization period only. We intended to provide a food supply which is similar to the one in the habitat where we collected the sea urchins. This was done to prevent food deprivation as this could influence the feeding behaviour of the animals [32]. During the acclimation period we did not monitor the amount of algal biomass that was consumed by the herbivores, but since faeces were observed in the tanks we assume that the sea urchins fed on the algal material that was provided.

\section{Experimental set-up}

The study consisted of three sequential stages: (i) assessing algal light compensation points, (ii) inducing light limitation and grazing, (iii) assessing grazer consumption rates in no-choice feeding assays after light limitation and grazer impact. For the latter we used the algal material from stage (ii) (Additional file 1). At all stages, indoor aquaria with a volume of $3.5 \mathrm{~L}$ $(17 \mathrm{~cm} \times 15 \mathrm{~cm} \times 14 \mathrm{~cm})$ served as experimental units. 


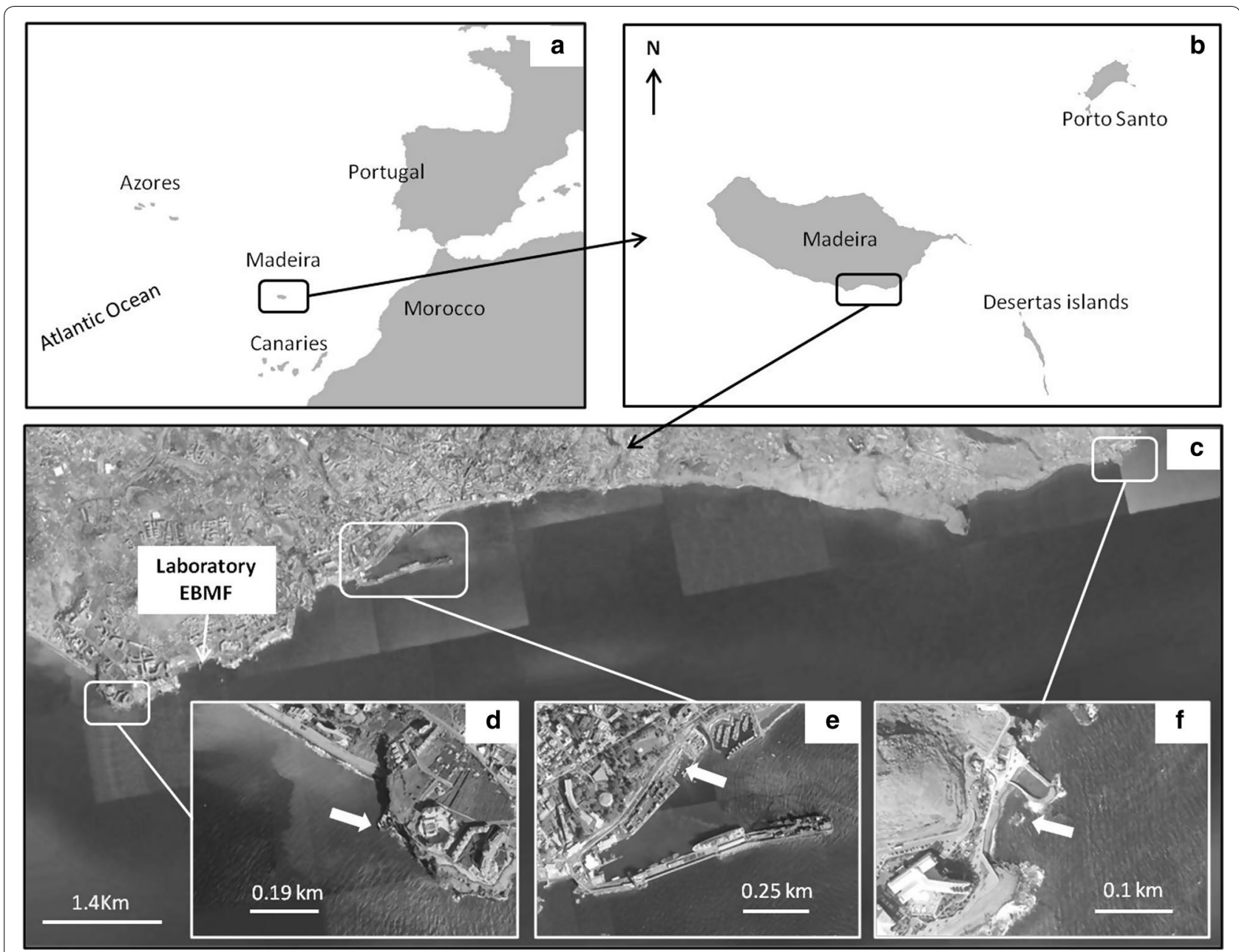

Fig. 1 Map of Madeira island $(\mathbf{a}, \mathbf{b})$ indicating the location of the laboratory and of the sites where organisms were collected $(\mathbf{c})$, Doca do Cavacas (Paracentrotus lividus) (d), Marina of Funchal (Grateloupia imbricata) (e), and Reis Magos (Stypopodium zonale) (f)

We supplied them with filtered sea water (mesh size: $1 \mathrm{~mm}$ ), which was pumped from Cais do Carvão Bay and stored in an outdoor tank $(10,000 \mathrm{~L})$ that was refilled every third day. Water temperature in the outdoor tank was $23 .{ }^{\circ} \mathrm{C} \pm 0.8{ }^{\circ} \mathrm{C}$ (mean $\pm \mathrm{SD}$ ), while the sea surface temperature in Funchal Bay ranges from 17 to $22.5{ }^{\circ} \mathrm{C}$ during the course of the year [40]. We kept the aquaria in a constant temperature room at $18{ }^{\circ} \mathrm{C}$ and renewed the water every day. All aquaria were placed on shelves and were aerated by pressured air diffusers, while the diurnal light rhythm was $12 / 12 \mathrm{~h}$ (light/dark). Light was provided by fluorescent lamps (OSRAM-36 W $6500 \mathrm{~K}$ Cool Daylight $120 \mathrm{~cm}$ ) that were mounted above the aquaria at a $15 \mathrm{~cm}$ distance to the water surface. Furthermore, the aquaria were wrapped in aluminium foil to prevent light entering from the sides. Absolute light intensities were determined with a light-meter (LLI-250 A, LI-COR, Nebraska, USA).

\section{Assessing light compensation points for G. imbricata and $S$. zonale}

Pilot studies were carried out in June 2007 to identify the Light Compensation Point (LCP) for both algal species, i.e. the light intensity at which the rate of photosynthesis (measured as oxygen production) equals respiration. For this, we reduced the amount of incoming light by placing various layers of black plastic gauze material with a mesh size of $1 \mathrm{~mm}$ on top of each aquarium. For both macroalgae, we had a total of 12 aquaria ( $3.5 \mathrm{~L}$ each) of with each was loaded with 30-40 g wet weight of seaweed material. We randomly assigned two aquaria to each of six different light regimes. The number of gauze layers used was $0,1,2,3,4$ and 5 . Algae were allowed to acclimatise under the different light regimes for 3 days, while water was exchanged every day. At the end of the third day, we stopped the water exchange and placed a Perspex lid on top of each aquarium to prevent any gas exchange with 
the atmosphere. For the following 4 days, we recorded the concentration of dissolved oxygen with an oxymeter (Oxi 197, WTW Wissenschaftlich-Technische Werkstätten $\mathrm{GmbH}$, Weilheim, Germany) twice a day. This was done once at the end of the dark period (09:00 am) to measure oxygen concentration after overnight depletion due to respiration and again once during the light period $(5: 00 \mathrm{pm})$ when photosynthesis is at maximum and after at least $8 \mathrm{~h}$ of oxygen production. An absence of diurnal fluctuations in oxygen concentration indicated that the provided light intensity is below the LCP of the respective seaweed species.

\section{Inducing light limitation and grazing}

Experiments were carried out in July 2007 for G. imbricata, and in September 2007 for S. zonale. We conducted a two-factorial experiment for each of the species in which we crossed two levels of grazing ("grazed" and "non-grazed") with six levels of light intensities (0-5 layers of gauze material) and each treatment combination was replicated eight times $(n=8)$. Consequently, we had $6 \times 8=48$ aquaria of which each contained one sea urchin, while another 48 aquaria had no sea urchins. The latter were used to determine total algal growth rates under the different light regimes in the absence of grazers and to provide non-grazed algal material for the feeding assays. In total we had 96 aquaria for each of the two seaweed species in the study and the respective treatments, i.e. light limitation and grazing, were imposed simultaneously for 21 days. Prior to this, each algal thallus was carefully shaken to remove adhered water and was weighed to the nearest $0.01 \mathrm{~g}$. We gave $30-40 \mathrm{~g}$ wet weight of algal material into each aquarium. In the case of G. imbricata, the urchins that we added had a mean $( \pm \mathrm{SD})$ weight of $13 \mathrm{~g} \pm 3 \mathrm{~g}$, while for $S$. zonale the weight of the urchins was $23 \mathrm{~g} \pm 3 \mathrm{~g}$. Algal biomass was assessed again at the end of the experiment and the biomass change during stress induction was calculated from nongrazed algal individuals. Sea water was exchanged every day during the time when we also inspected all aquaria for Dead Sea urchins-which were replaced by living ones immediately.

\section{Assessing grazer consumption rates in no-choice feeding assays}

We tested for possible effects of the previously applied light limitation and grazing [see stage (ii)] on grazer consumption rates in no-choice feeding assays that lasted for $24 \mathrm{~h}$. Hence, the number of replicates for the assays at stage (iii) was the same as at stage (ii). However, we used other individuals of $P$. lividus than the ones we had for stage (ii). Similar studies that assessed grazer consumption rates for amphipods showed that the no-choice feeding assays produce results, which are not different from the outcomes of choice-feeding assays $[48,49]$. For the assays, we cut and then placed fragments of seaweed material $(0.5-1 \mathrm{~g})$ in additional aquaria (i.e. feeding arenas). Fragments came from each of the two grazing regimes (previously grazed and nongrazed), and were weighed before and after the preference tests. We inserted one previously weighed sea urchin individual into each aquarium to graze on the algal piece. Additionally, we had a growth control for each seaweed species, in which grazers were absent, to assess the autogenic change in algal biomass during the time of the assay [28]. Light conditions during the feeding assays were the same as for the algal fragments that did not experience light limitation (i.e. 0 gauze layers) during the experiment. For this we cut a fragment from each algal replicate, placed it in a separate aquarium and quantified its growth during the time of the feeding assay.

Grazer consumption rates of algal material were determined as the grazers' total consumption, which was calculated using the equation suggested by Cronin and Hay [28]:

$$
\left[\mathrm{A}_{i} \times\left(\mathrm{C}_{f} / \mathrm{C}_{i}\right)-\mathrm{A}_{f}\right]
$$

where $\mathrm{A}_{i}$ and $\mathrm{A}_{f}$ were the initial and final weight of the algae portions used in the feeding assays; $C_{i}$ and $C_{f}$ are the equivalent weights of the growth control algal pieces before and after the assays [50]. Finally, consumption rates were standardised for grazer wet biomass ( $\mathrm{g}$ alga/g grazer). Negative consumption was recorded in case algal growth rates during the assays exceeded consumption rates.

\section{Statistical analyses}

Relationships between algal growth and light intensity at experimental stage (ii), i.e. induction of light limitation and grazing pressure, were analysed with simple linear regression. A $t$ test was used to test for differences in sea urchin grazing rates between algal species at stage (iii), i.e. assessing grazer consumption rates with no-choice feeding assays. For this comparison we used only the algal material that was not previously exposed to grazing to avoid any bias due to grazing history. Furthermore, a two-factorial ANOVA tested for significant effects of "Grazing" (with two levels: "grazed" and "nongrazed") and "Light" (with six levels of light intensity) on grazer consumption rates at this stage of the experiment. Normality of errors and homogeneity of variances were tested with graphical tools and data were log transformed prior to t-testing and ANOVA. All analyses were done using the free statistical R Version 3.0.3 "Warm Puppy" [51] and STATISTICA 7.0 [52]. 


\section{Results}

Light intensity levels and light compensation points (LCPs) The intensity of the light emitted by the fluorescent lamps we used was $27 \mu \mathrm{mol} \mathrm{m} \mathrm{m}^{-2} \mathrm{~s}^{-1}$ and we reduced this by adding 1-5 layers of gauze on top of each aquarium, resulting in a total of 6 different light levels. The amount of light that passed through the gauze layers varied between $18 \mu \mathrm{mol} \mathrm{m}{ }^{-2} \mathrm{~s}^{-1}$ (with 1 layer) and $3 \mu \mathrm{mol} \mathrm{m}{ }^{-2}$ $\mathrm{s}^{-1}$ (with 5 layers) (Table 1). The LCP for Stypopodium zonale was determined to be at $6 \mu \mathrm{mol} \mathrm{m} \mathrm{m}^{-2} \mathrm{~s}^{-1}$, whereas for Grateloupia imbricata the LCP was at $5 \mu \mathrm{mol} \mathrm{m}{ }^{-2} \mathrm{~s}^{-1}$ (Additional file 2a, b).

\section{Algal growth as a function of light intensity}

We found no effect of light limitation on growth in $S$. zonale. This alga exhibited a positive growth rate of $30 \%$ within 21 days under all light conditions $\left(r^{2}=0.03\right.$, $\mathrm{p}=0.27$, Fig. 2a). In contrast to this, G. imbricata consistently showed negative growth rates regardless of light intensity. Mean biomass losses in this species ranged from 7 to $18 \%$ within 21 days under light intensities ranging from 27 to $3 \mu \mathrm{mol} \mathrm{m} \mathrm{m}^{-2} \mathrm{~s}^{-1}\left(\mathrm{r}^{2}=0.32, \mathrm{p}<0.01\right.$, Fig. 2b).

\section{Algal attractiveness for Paracentrotus lividus}

In case of the non-grazed algal material (pooled across all light levels), sea urchins grazed significantly more on the native seaweed $S$. zonale than on the non-native algal species G. imbricata ( $t$ test: $\mathrm{t}=5.07, \mathrm{p} \leq 0.001$ ) (Fig. 3). The fact that the median consumption on $G$. imbricata was smaller than zero actually means that many urchin individuals did not graze on this species at all or that their consumption was overcompensated by algal growth during the assays. In case of S. zonale, almost all sea urchin individuals grazed the algae at a rate that exceeded autogenic change. The median difference in grazing on the two species was $0.0124 \mathrm{~g}$ alga/g grazer $/ 24 \mathrm{~h}$. The sea urchins consumed a maximum of $30 \%$ of the offered algal biomass during the 21 days of the experiment.

Table 1 Light intensity levels realized by placing different numbers of gauze layers on top of the experimental units

\begin{tabular}{|c|c|c|}
\hline $\begin{array}{l}\text { No. of gauze } \\
\text { layers }\end{array}$ & $\begin{array}{l}\text { Absolute light intensity } \\
\left(\mu \mathrm{mol} \mathrm{m} \mathrm{m}^{-2} \mathrm{~s}^{-1}\right)\end{array}$ & $\begin{array}{l}\text { Relative light } \\
\text { intensity (\%) }\end{array}$ \\
\hline 0 & 27 & 100 \\
\hline 1 & 18 & 66.7 \\
\hline 2 & 11 & 40.7 \\
\hline 3 & 6 & 22.2 \\
\hline 4 & 5 & 18.5 \\
\hline 5 & 3 & 11.1 \\
\hline
\end{tabular}
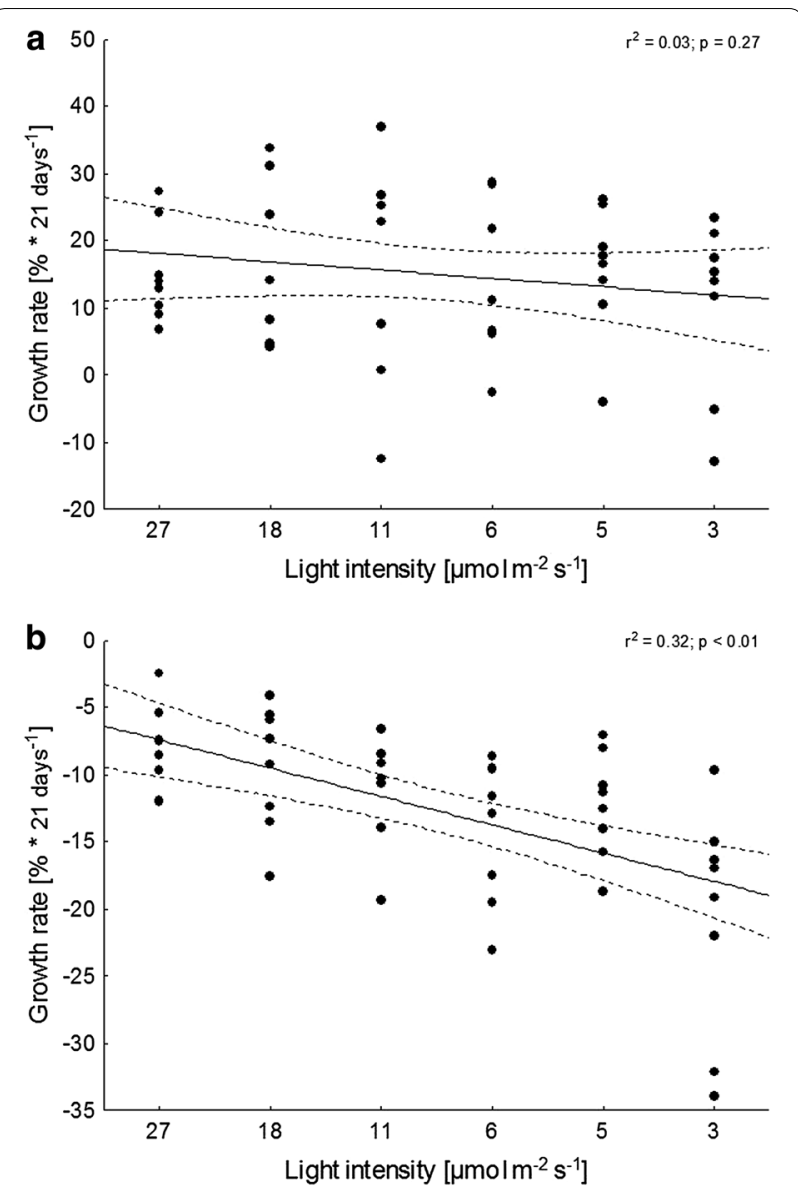

Fig. 2 Algal growth as a function of light intensity in Stypopodium zonale (a) and Grateloupia imbricata (b) after 21 days under different light regimes in the absence of grazers. Regression line $\pm 95 \% \mathrm{Cl}$ in $\mathbf{a} r^{2}=0.03$ and $p=0.27$, and in $\mathbf{b} r^{2}=0.32$ and $p<0.01$. Please note that the $x$ variable decreases from left to right

Grazer consumption rates as a function of previous grazing and light intensity

Three weeks of ongoing herbivory by sea urchins at stage (ii) of the experiment affected the consumption of algal material by other grazer individuals at stage (iii) of the experiment. The direction of the effect, however, varied between the algal species. In $S$. zonale, previous herbivory lowered grazer consumption rates when compared to non-grazed algal material (Fig. 4a). This was the case under all but two light regimes, i.e. the highest and the lowest light availability. This resulted in a marginally significant interaction between the two factors "Light" and "Grazing" (Table 2). In G. imbricata, previous grazing enhanced grazer consumption rates significantly and this effect was consistent across light levels (Fig. 4b). At the same time, light availability had no influence on grazer consumption of the non-native seaweed species (Table 2). 


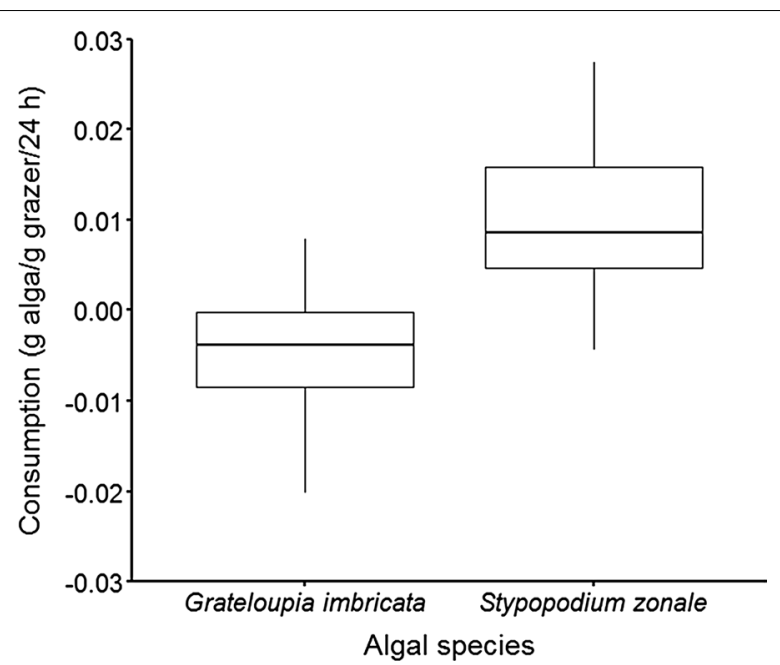

Fig. 3 Consumption of the non-native macroalga Grateloupia imbricata and the native seaweed Stypopodium zonale by the sea urchin Paracentrotus lividus. Data were pooled across all light levels

\section{Discussion}

In this study we compared the attractiveness for a macrograzer and resistance to light limitation between a native and a non-native macroalgal species. We found that the native Stypopodium zonale was a more attractive food source for the sea urchins, which we used as consumers, than the non-native Grateloupia imbricata. Although we only investigated one specific combination of a nonnative and a native macroalgal species, this observation generally supports the predictions of the ERH $[14,53]$. The latter suggests that non-native plants experience less herbivory, because they (a) left their coevolved consumers behind and (b) herbivores in the recipient environment fail to recognize them as a food source. The suggestion that non-native species are less attractive for herbivores than native species has been tested for mesoand macrograzer consumption of marine macroalgae in several laboratory experiments [54-56]. Although the outcomes were in the most cases ambiguous, the studies showed that grazers frequently prefer native over nonnative algal species-what was again confirmed by the results of this study. Two of these studies also used the macrograzer $P$. lividus and found that this species prefers several native seaweed species from the coast of Portugal over the non-native Sargassum muticum [54] and the native seagrass Posidonia oceanica over the non-native macroalgal species Lophocladia lallemandii, Acrothamnion preissii and Womersleyella setacea [57]. Cacabelos, Olabarria [58] reported that native gastropod grazers (Littorina littorea, L. obtusata and Aplysia punctata) preferred native macroalgae over the invasive S. muticum in most cases, while the P. lividus individuals that

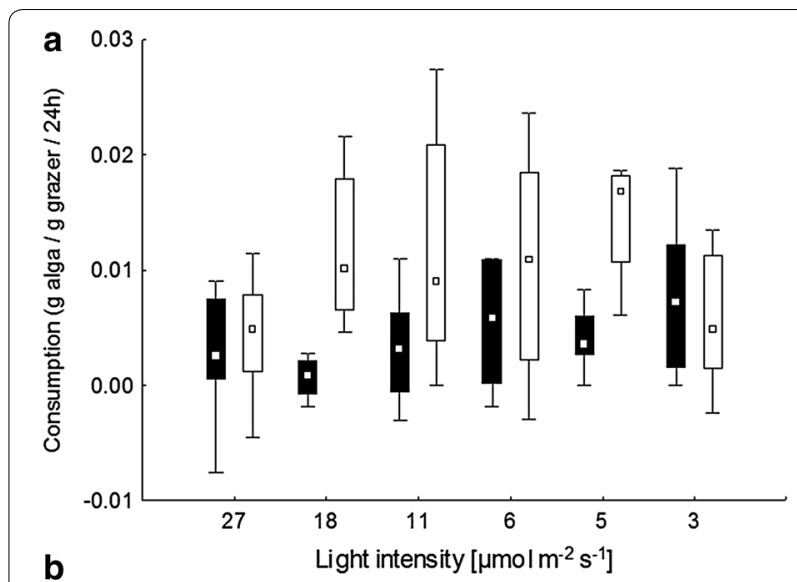

b

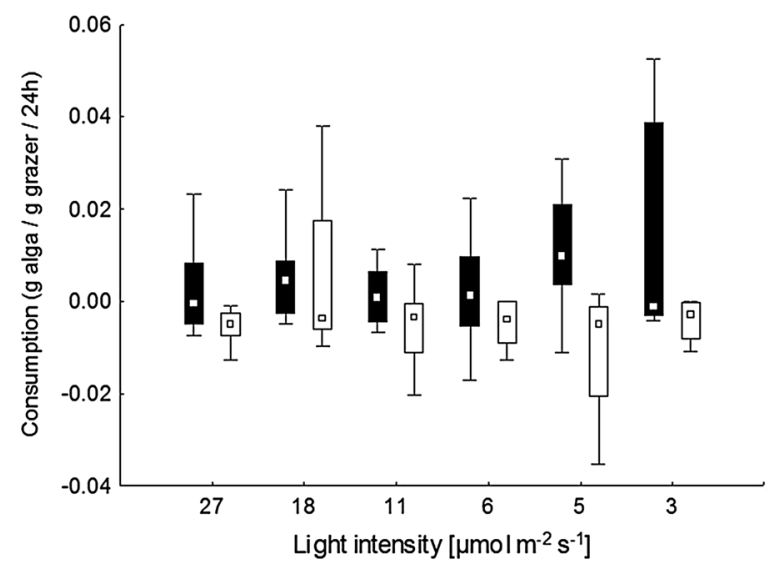

Fig. 4 Consumption of the native Stypopodium zonale (a) and the non-native Grateloupia imbricata (b) by Paracentrotuis lividus as a function of previous grazing and light intensity. Results from no-choice feeding assays. Median, interquartiles, non-outlier range; $\mathrm{n}=8$. Black boxes show consumption of previously grazed algal material and white boxes show consumption of intact algal material. Please note that the $x$ variable decreases from left to right

they tested showed no preference. Furthermore, analyses of the gut content of $P$. lividus collected in the western Mediterranean Sea, i.e. in Saména, Gulf of Marseilles (France), in the Archipelago of Cabrera National Park and in St Elm, Mallorca (Spain), revealed the absence of numerous non-native macroalgae (i.e. Caulerpa racemosa, L. lallemandii, W. setacea and A. preissi) from the diet of this species although they are abundant in the regions where the sea urchins were collected. This suggests that $P$. lividus generally avoids the consumption of non-native macroalgae $[59,60]$.

\section{Consequences of light limitation for algal growth and grazer consumption rates}

Light reduction limited growth in G. imbricata but not in S. zonale. It seems likely that the first algal species, or at least the population that we sampled, is adapted to high 
Table 2 Effects of grazing and light intensity on the consumption of the native Stypopodium zonale and the non-native Grateloupia imbricata by Paracentrotus lividus as assessed in no-choice feeding assays

\begin{tabular}{|c|c|c|c|c|c|}
\hline Source of variation & SS & $d f$ & MS & $F$ & $p$ \\
\hline \multicolumn{6}{|l|}{ Stypopodium zonale } \\
\hline Grazing & $<0.001$ & 1 & $<0.001$ & 15.302 & $<0.001$ \\
\hline Light & $<0.001$ & 5 & $<0.001$ & 1.856 & 0.111 \\
\hline Light $\times$ Grazing & $<0.001$ & 5 & $<0.001$ & 2.451 & 0.040 \\
\hline \multicolumn{6}{|l|}{ Grateloupia imbricata } \\
\hline Grazing & $<0.002$ & 1 & $<0.002$ & 6.130 & 0.015 \\
\hline Light & $<0.002$ & 5 & $<0.001$ & 1.102 & 0.365 \\
\hline Light $\times$ Grazing & 0.002 & 5 & $<0.001$ & 1.610 & 0.166 \\
\hline
\end{tabular}

Results from two-factorial ANOVA. Significant differences are shown in italics

light conditions, since we found it growing attached to pontoons at a water depth of $0.5 \mathrm{~m}$. Interestingly, the light compensation point of G. imbricata was found to be at $5 \mu \mathrm{mol} \mathrm{m}{ }^{-2} \mathrm{~s}^{-1}$ and was therefore only slightly below the one for S. zonale $\left(6 \mu \mathrm{mol} \mathrm{m}{ }^{-2} \mathrm{~s}^{-1}\right)$. Therefore, G. imbricata should be able to grow in greater depths than in which we actually found it in Madeiran waters and its vertical distributional range should overlap with the one of $S$. zonale. We collected the latter species in water depths of 3-7 $\mathrm{m}$ and it was not affected by the light deficiency we realized in the experiments. This shows that, although the assessed light compensation points were very similar, the two species differ in their capacity to deal with low light conditions. The fact that, $S$. zonale even grew at light intensities below its light compensation point suggests that it can acclimate to light deficiency at least at short time scales. This is in accordance with our observation that its fronds got darker during the experiment (P. Ramalhosa, pers. obs.), what indicates that the density of photosensitive pigments increased as a reaction to low light conditions [61]. A further possible explanation for its tolerance is that $S$. zonale was able to mobilise stored resources to compensate for the limitation in carbohydrate synthesis. The latter strategy has been described for the bladder wrack $F$. vesiculosus from the Baltic Sea [62]. At high latitudes, e.g. in the northern and eastern part of the Baltic Sea, seaweeds experience strong fluctuations in light intensity throughout the year-not only due to a reduction in light intensity and hours of daylight in winter but also due to ice cover. Energy-rich compounds, which are synthesized and stored during phases of high light availability, can then fuel algal life activities when light is scarce. However, S. zonale is a warm-water species that is abundant along the coasts of the tropical Pacific and Atlantic Ocean [45] and does not occur in areas where day lengths undergo substantial fluctuations. It is therefore doubtful whether it evolved the capacity to store large amounts of carbohydrates.
For $S$. zonale we found that previous grazing by the sea urchin P. lividus made the algal tissue less attractive for conspecifics. This could go back to the onset of a chemical protection, i.e. an inducible defence, as it has already been this described for several seaweed species [29, 63]. However, this effect was pronounced under two out of the six light regimes we applied (i.e. 5 and $18 \mu \mathrm{mol} \mathrm{m}^{-2} \mathrm{~s}^{-1}$ ) and basically absent under two others (i.e. 3 and $27 \mu \mathrm{mol} \mathrm{m}{ }^{-2}$ $\mathrm{s}^{-1}$ ). This led to a marginally significant interaction between the factors "Grazing" and "Light". This finding is not conclusive, since the distribution of discriminative grazing across the light gradient did not follow a plausible pattern. If the limitation in energy supply compromised the synthesis of secondary metabolites or weakened mechanical defences such as tissue toughness, the capacity to defend should have decreased with decreasing light availability [64]. The pattern we observed, i.e. high defence at intermediate light levels and a low defence under the highest and the lowest light availability, is therefore difficult to explain. The absence of a defence under low-light conditions may indicate that the amount of energy gained from photosynthesis at this light level was too low to allow defence induction. However, we cannot explain the absence of a defence under the highest irradiation regime. It was certainly not due to high light stress that could have led to photoinhibition in S. zonale, since the alga showed positive growth rates under these light conditions.

The picture was different in G. imbricata, because previous grazing by sea urchins made this alga more attractive for conspecifics and this effect was consistent across the light gradient. Hence, no interaction between "Grazing" and "Light" was observed.

Furthermore, grazer consumption of non-grazed G. imbricata individuals did not change across the light gradient, thus light depletion alone did not affect algal attractiveness for the sea urchins.

Although we cannot elicit the underlying mechanism, we suggest that within the 21 days during which we 
imposed our treatments, an additive effect of the two stressors (i.e. light reduction and grazer attack) weakened G. imbricata and by this lowered the nutritional quality of the tissue. As a consequence of this, P. lividus could have exhibited compensatory feeding by preferring and consuming more of the previously grazed than of the non-grazed seaweed material. This is a common adaptive response of herbivores when faced with low quality food [65, 66] and was also observed by Tomas, Box [57] in no-choice feeding assays with C. racemosa and P. lividus. However, if this assumption is correct, it is surprising that grazer consumption rates did not increase with decreasing light availability.

In our study, the non-native G. imbricata turned out to be more susceptible to light deficiency (resulting in reduced growth) and grazing (resulting in increased grazer consumption rates) than the native $S$. zonale. These two observations do not corroborate the assumption that enemy release is associated with an increased tolerance to abiotic stress or that it could enhance the capacity to defend against herbivores-both through the re-allocation of energy that is available because other defences were reduced. And they also do not support the widely discussed notion that non-native photoautotrophs are generally more robust towards abiotic stress than comparable native species $[67,68]$.

Previous studies on the effects of light reduction on defences against consumers in seaweeds, which used similar experimental approaches, came to conflicting results. Pansch, Cerda [35] found no effect of light limitation on chemically mediated defences against grazers and foulers in four brown algae from the coast of Chile and Appelhans, Lenz [34] reported the same for five seaweed species from the coast of Brazil (one green, two red, two brown including S. zonale). In contrast to this, Kubicek, Bessho [64] observed that grazing rates of the snail Lacuna smithii on the red alga Chondrus yendoi increased with decreasing light availability. However, the authors were not able to elicit whether energy shortage affected tissue quality, such as toughness, or whether chemical defences were impaired. Such an impairment under low light conditions was observed for the trophic interaction between the bladder wrack Fucus vesiculosus and the isopod Idotea baltica [8]. Here, during phases of light limitation, chemical defence induction was largely inhibited.

\section{Inducible defences in Stypopodium zonale}

We detected hints for the presence of an inducible defence against herbivory in $S$. zonale after 21 days of grazing by the sea urchin $P$. lividus. This is a new finding, since previous studies on this seaweed from Brazil only reported the presence of constitutive chemical defences against amphipods and sea urchins $[39,69]$. Gerwick and Fenical [70] reported the accumulation of rust-coloured substances in the aquaria in which the algae were kept, while this was also observed in this study (P. Ramalhosa, pers. obs.) and additionally found the compound Stypoldione as a major component of these exudates, which proved to have a strong narcotic and toxic effect on herbivorous fish. Furthermore, it reduces feeding by the sea urchin Diadema antillarum [71]. Consistent with this, Soares, Teixeira [45] reported that natural concentrations of secondary metabolites in $S$. zonale effectively deter feeding by the sea urchin Lytechinus variegatus and the crab Pachygrapsus transversus. However, although appropriate tests have been made, no inducible defences were described for $S$. zonale so far $[69,72]$. Weidner, Lages [69] reported that S. zonale from the coast of Brazil did not show defence induction as a reaction to amphipod grazing, but has a constitutive chemical activity that killed amphipods within 2 days. A permanent defence is an advantageous adaptation in habitats where grazing pressure does not undergo seasonal fluctuations and is therefore predictable. We assume that S. zonale from Madeira is also permanently defended, because of the accumulation of rust-coloured substances that we observed in the experimental aquaria. However, we additionally found hints for an inducible defence in $S$. zonale that was triggered by urchin grazing and possibly serves to supplement a permanent resistance when grazing pressure becomes intense.

In summary, we found that the non-native macroalga G. imbricata was less attractive for the sea urchin $P$. lividus from the coastal waters of Madeira Island than the native S. zonale. This supports the enemy release hypothesis that proposes that introduced species are released from their natural enemies and therefore experience less predation or herbivory. However, our findings cannot confirm that the release from enemies was also associated with an increased tolerance to abiotic stress or a higher capacity to defend against herbivory in $G$. imbricata. Furthermore, they do not support the notion that non-native species are generally more tolerant to environmental stress than comparable native species.

\section{Additional files}

Additional file 1. The study consisted of three sequential stages: (i) assessing algal light compensation points, (ii) inducing light limitation and grazing and (iii) assessing grazer consumption rates in no-choice feeding assays after light limitation and grazer impact.

Additional file 2. Fluctuations in oxygen concentration over time under different light regimes ( $0-5$ gauze layers). The light compensation point for Stypopodium zonale a was at $6 \mu \mathrm{mol} \mathrm{m} \mathrm{m}^{-2} \mathrm{~s}^{-1}$ and for Grateloupia imbricata $\mathbf{b}$ at $5 \mu \mathrm{mol} \mathrm{m} \mathrm{m}^{-2} \mathrm{~s}^{-1}$

Additional file 3. Datasets of the light compensation points and of the effects of grazing and light intensity on the consumption of the native Stypopodium zonale and the non-native Grateloupia imbricata by Paracentrotus lividus in laboratory experiment on Madeira Island in 2007. 


\section{Abbreviations}

ERH: enemy release hypothesis; LCP: light compensation point; GAME: Global Approach by Modular Experiments; OOM: Observatório Oceânico da Madeira; ERDF: European Regional Development Fund.

\section{Authors' contributions}

PR executed the experimental study, attained the data, performed the statistical analysis and its interpretation, and drafted the manuscript. SD executed the experimental study, attained the data and participated in the critical revision of the manuscript. MK participated in the design and coordination of the study and helped with the critical revision of the manuscript. ML conceived of the study, participated in its design and coordination, statistical analysis, interpretation of data and helped to draft and revise the manuscript. All authors read and approved the final manuscript.

\section{Author details}

${ }^{1}$ Present Address: MARE - Marine and Environmental Sciences Centre, Quinta do Lorde Marina, Sítio da Piedade, 9200-044 Caniçal, Madeira Island, Portugal. ${ }^{2}$ Faculty of Life Sciences, University of Madeira, Marine Biology Station of Funchal, 9000-107 Funchal, Madeira Island, Portugal. ${ }^{3}$ Animal Ecology, Evolution and Biodiversity, Ruhr-Universität Bochum, 44801 Bochum, Germany. ${ }^{4}$ Present Address: Zdi-Zentrum BeST, Bergisches Schul-Technikum, Bergische Universität Wuppertal, Rainer-Gruenter-Straße 21, 42119 Wuppertal, Germany. ${ }^{5}$ CIIMAR/CIMAR - Centre of Marine and Environmental Research, Rua dos Bragas 289, 4050-123 Porto, Portugal. ${ }^{6}$ CIIMAR-Madeira - Interdisciplinary Centre of Marine and Environmental Research of Madeira, Edif. Madeira Tecnopolo, Caminho da Penteada, 9020-105 Funchal, Madeira Island, Portugal. ${ }^{7}$ Marine Ecology Department, GEOMAR Helmholtz Centre for Ocean Research, Düsternbrooker Weg 20, 24105 Kiel, Germany.

\section{Acknowledgements}

We are grateful to all members and staff of the Marine Biology Station of Funchal and of the University of Madeira for their indispensable advice and logistic support. We thank especially N. Cordeiro, A. Nunes, F. Erra, R. Barradas and A. Faria for their invaluable help. The project was funded by the Mercator Foundation and was part of the international student training and research programme GAME (Global Approach by Modular Experiments), which is coordinated by GEOMAR Helmholtz Centre for Ocean Research Kiel. P. Ramalhosa holds a research fellowship in the Project Observatório Oceânico da MadeiraOOM (M1420-01-0145-FEDER-000001), co-financed by the Madeira Regional Operational Programme (Madeira 14-20), under the Portugal 2020 strategy, through the European Regional Development Fund (ERDF). This is contribution number 33 of Marine Biology Station of Funchal. We thank J. Canning-Clode and I. Gestoso for their encouragement and for reading an earlier version of this manuscript. We also would like to thank two anonymous reviewers who, with their comments, improved the quality of this contribution substantially.

\section{Competing interests}

The authors declare that they have no competing interests.

\section{Availability of data and materials}

The additional files and datasets (raw data) supporting the conclusions of this article are available at http://doi.org/10.1594/PANGAEA.867730.

\section{Funding}

The project was funded by the Mercator Foundation and was part of the international student training and research programme GAME (Global Approach by Modular Experiments) of GEOMAR.

Received: 7 May 2016 Accepted: 4 November 2016

Published online: 21 December 2016

\section{References}

1. Vitousek P, et al. Human domination of earth's ecosystems. In: Marzluff $J$, et al., editors. Urban ecology - an international perspective on the interaction between humans and nature. Berlin: Springer; 2008. p. 3-13.

2. Carlton JT. Global change and biological invasions in the oceans. In: Mooney HA, Hobbs RJ, editors. Invasive species a changing world. Washington D.C.: Island Press; 2000. p. 31-53.
3. Shea K, Chesson P. Community ecology theory as a framework for biological invasions. Trends Ecol Evol. 2002;17(4):170-6.

4. Van Kleunen M, Weber E, Fischer M. A meta-analysis of trait differences between invasive and non-invasive plant species. Ecol Lett. 2010;13(2):235-45.

5. Davidson AM, Jennions M, Nicotra AB. Do invasive species show higher phenotypic plasticity than native species and if so, is it adaptive? A metaanalysis. Ecol Lett. 2011;14(4):419-31.

6. Zerebecki RA, Sorte CJ. Temperature tolerance and stress proteins as mechanisms of invasive species success. PLOS ONE. 2011;6(4):e14806.

7. Zardi G, et al. Sand and wave induced mortality in invasive (Mytilus galloprovincialis) and indigenous (Perna perna) mussels. Mar Biol. 2008;153(5):853-8.

8. Weinberger $F$, et al. Effects of limitation stress and disruptive stress on induced antigrazing defense in the bladder wrack Fucus vesiculosus. Mar Ecol Prog Ser. 2011;427:83-94.

9. Weinberger F, et al. The invasive red alga Gracilaria vermiculophylla in the Baltic Sea: adaptation to brackish water may compensate for light limitation. Aquat Biol. 2008;3(3):251-64.

10. Lenz $M$, et al. Non-native marine invertebrates are more tolerant towards environmental stress than taxonomically related native species: results from a globally replicated study. Environ Res. 2011;111(7):943-52.

11. Crain CM, Kroeker $K$, Halpern BS. Interactive and cumulative effects of multiple human stressors in marine systems. Ecol Lett. 2008;11(12):1304-15

12. Hughes AR, et al. Ecological consequences of genetic diversity. Ecol Lett. 2008;11(6):609-23.

13. Agrawal AA, et al. Enemy release? an experiment with congeneric plant pairs and diverse above-and belowground enemies. Ecology. 2005;86(11):2979-89.

14. Keane RM, Crawley MJ. Exotic plant invasions and the enemy release hypothesis. Trends Ecol Evol. 2002;17(4):164-70.

15. Liu H, Stiling P. Testing the enemy release hypothesis: a review and metaanalysis. Biol Inv. 2006;8(7):1535-45.

16. Nejrup LB, Pedersen MF, Vinzent J. Grazer avoidance may explain the invasiveness of the red alga Gracilaria vermiculophylla in Scandinavian waters. Mar Biol. 2012;159(8):1703-12.

17. Colautti Rl, et al. Is invasion success explained by the enemy release hypothesis? Ecol Lett. 2004;7(8):721-33.

18. Jeschke J, et al. Support for major hypotheses in invasion biology is uneven and declining. NeoBiota. 2012;14:1.

19. Schaffelke B, Smith JE, Hewitt CL. Introduced macroalgae-a growing concern. In: Eighteenth international seaweed symposium. Springer; 2006.

20. McClelland JW, Valiela I. Changes in food web structure under the influence of increased anthropogenic nitrogen inputs to estuaries. Mar Ecol Prog Ser. 1998;168:259-71.

21. Zenetos A et al. Alien species in the Mediterranean Sea by 2010. A contribution to the application of European Union's Marine Strategy Framework Directive (MSFD). Part I. Spatial distribution. 2010.

22. Hewitt CL, Campbell ML, Schaffelke B. Introductions of seaweeds: accidental transfer pathways and mechanisms. Bot Mar. 2007;50(5/6):326-37.

23. Williams SL, Smith JE. A global review of the distribution, taxonomy, and impacts of introduced seaweeds. Annu Rev Ecol Evol Syst. 2007;38:327-59.

24. Gruner DS, et al. A cross-system synthesis of consumer and nutrient resource control on producer biomass. Ecol Lett. 2008;11(7):740-55.

25. Ling $S$, et al. Global regime shift dynamics of catastrophic sea urchin overgrazing. Philos Trans R Soc Lond B Biol Sci. 2015;370(1659):20130269.

26. Duffy JE, Hay ME. Seaweed adaptations to herbivory-chemical, structural, and morphological defenses are often adjusted to spatial or temporal patterns of attack. Bioscience. 1990;40(5):368-75.

27. Hay ME. Marine chemical ecology: what's known and what's next? J Exp Mar Biol Ecol. 1996;200:103-34.

28. Cronin G, Hay ME. Induction of seaweed chemical defenses by amphipod grazing. Ecology. 1996;77(8):2287-301

29. Toth GB, Pavia H. Induced herbivore resistance in seaweeds: a metaanalysis. J Ecol. 2007;95(3):425-34.

30. Rohde S, Molis M, Wahl M. Regulation of anti-herbivore defence by Fucus vesiculosus in response to various cues. J Ecol. 2004;92:1011-8.

31. Ceh J, et al. Induction and reduction of anti-herbivore defenses in brown and red macroalgae off the Kenyan coast. J Phycol. 2005;41(4):726-31. 
32. Cronin G, Hay ME. Susceptibility to herbivores depends on recent history of both the plant and animal. Ecology. 1996;77(5):1531-43.

33. Ralph P, et al. Impact of light limitation on seagrasses. J Exp Mar Biol Ecol. 2007;350(1):176-93.

34. Appelhans Y, et al. Stressed, but not defenceless: no obvious influence of irradiation levels on antifeeding and antifouling defences of tropical macroalgae. Mar Biol. 2010;157(5):1151-9.

35. Pansch C, et al. Consequences of light reduction for anti-herbivore defense and bioactivity against mussels in four seaweed species from northern-central Chile. Mar Ecol Prog Ser. 2009;381:83-97.

36. de Lamarck JBM. Histoire naturelle des animaux sans vertèbres. Tome second. Paris: Verdière; 1816. p. 568.

37. Papenfuss GF. Notes on South African marine algae. I Bot Notiser 1940; 200-226.

38. Holmes EM. New marine algae from Japan. Linn Soc London Bot. 1896:31:248-60.

39. Pereira RC, et al. Variation in chemical defenses against herbivory in southwestern Atlantic Stypopodium zonale (Phaeophyta). Bot Mar. 2004;47:202-8.

40. Alves $F$, et al. Algal cover and sea urchin spatial distribution at Madeira Island (NE Atlantic). Sci Mar. 2001;65:383-92.

41. Verlaque M, et al. The genus Grateloupia C. Agardh (Halymeniaceae, Rhodophyta) in the Thau Lagoon (France, Mediterranean): a case study of marine plurispecific introductions. Phycologia. 2005;44(5):477-96.

42. Ferreira $S$ et al. New records of Macroalgae from Madeira Archipelago. In: International Symposium FloraMac2012, 5-8 de September, Madeira, Portugal 2012.

43. Garcia-Jimenez P, et al. Red alga Grateloupia imbricata (Halymeniaceae), a species introduced into the Canary Islands. Phycol Res. 2008;56:166-71.

44. Montes M, et al. Morphological and molecular methods reveal the Asian alga Grateloupia imbricata (Halymeniaceae) occurs on Cantabrian Sea shores (Bay of Biscay). Phycologia. 2016;55(4):365-70.

45. Soares AR, et al. Variation on diterpene production by the Brazilian alga Stypopodium zonale (Dictyotales, Phaeophyta). Biocheml Syst Ecol. 2003;31:1347-50

46. Littler M, Taylor P, Littler D. Algal resistance to herbivory on a Caribbean barrier reef. Coral Reefs. 1983;2(2):111-8.

47. Littler M, Taylor PR, Littler DS. Plant defense associations in the marine environment. Coral Reefs. 1986;5:63-71.

48. Macaya EC, Thiel M. In situ tests on inducible defenses in Dictyota kunthii and Macrocystis integrifolia (Phaeophyceae) from the Chilean coast. J Exp Mar Biol Ecol. 2008:354:28-38.

49. Pansch C, et al. Species-specific defense strategies of vegetative versus reproductive blades of the Pacific kelps Lessonia nigrescens and Macrocystis integrifolia. Mar Biol. 2008;155(1):51-62.

50. Sotka EE, Taylor RB, Hay ME. Tissue-specific induction of resistance to herbivores in a brown seaweed: the importance of direct grazing versus waterborne signals from grazed neighbors. J Exp Mar Biol Ecol. 2002;277(1):1-12.

51. R Development Core Team. R: a language and environment for statistical computing. R Foundation for Statistical Computing, Vienna, Austria. www.R-project.org (2014).

52. STATSOFT. Statistica: data analysis software system: version 7.0. Tulsa: Statsoft (2004).
53. Elton CS. The ecology of invasions by animals and plants. Chicago: University of Chicago Press; 2000

54. Monteiro CA, Engelen AH, Santos RO. Macro-and mesoherbivores prefer native seaweeds over the invasive brown seaweed Sargassum muticum: a potential regulating role on invasions. Mar Biol. 2009;156(12):2505-15.

55. Engelen AH, et al. Mesograzers prefer mostly native seaweeds over the invasive brown seaweed Sargassum muticum. Hydrobiologia. 2011;669(1):157-65.

56. Yun $\mathrm{H}$, Molis M. Comparing the ability of a non-indigenous and a native seaweed to induce anti-herbivory defenses. Mar Biol. 2012:159(7):1475-84.

57. Tomas F, Box A, Terrados J. Effects of invasive seaweeds on feeding preference and performance of a keystone Mediterranean herbivore. Biol Inv. 2011;13(7):1559-70

58. Cacabelos E, et al. Do grazers prefer invasive seaweeds? J Exp Mar Biol Ecol. 2010:393(1):182-7.

59. Ruitton S, et al. Grazing on Caulerpa racemosa var. cylindracea (Caulerpales, Chlorophyta) in the Mediterranean Sea by herbivorous fishes and sea urchins. Vie et Milieu. 2006;56(1):33-42.

60. Cebrian $\mathrm{E}$, et al. Do native herbivores provide resistance to Mediterranean marine bioinvasions? a seaweed example. Biol Inv. 2011;13(6):1397-408.

61. Kirk JT. Light and photosynthesis in aquatic ecosystems. Cambridge: Cambridge University Press; 1994.

62. Lehvo AS, Bäck KM. Growth of Fucus vesiculosus L. (Phaeophyta) in the Northern Baltic Proper: energy and nitrogen storage in seasonal environment. Bot Mar. 2001:44(4):345-50.

63. Molis M, et al. Specificity of inducible seaweed anti-herbivory defences depends on identity of macroalgae and herbivores. Mar Ecol Prog Ser. 2008:354:97-105.

64. Kubicek A, et al. Inducible defence and its modulation by environmental stress in the red alga Chondrus yendoi (Yamada and Mikami in Mikami, 1965) from Honshu Island, Japan. J Exp Mar Biol Ecol. 2011;397(2):208-13.

65. Cruz-Rivera E, Hay ME. Can quantity replace quality? food choice, compensatory feeding, and fitness of marine mesograzers. Ecology. 2000;81(1):201-19.

66. Cruz-Rivera E, Hay ME. Prey nutritional quality interacts with chemical defenses to affect consumer feeding and fitness. Ecol Monogr. 2003;73(3):483-506.

67. Parker JD, et al. Do invasive species perform better in their new ranges? Ecology. 2013;94(5):985-94.

68. Alba C, Hufbauer R. Exploring the potential for climatic factors, herbivory, and co-occurring vegetation to shape performance in native and introduced populations of Verbascum thapsus. Biol Inv. 2012;14(12):2505-18.

69. Weidner $\mathrm{K}$, et al. Effect of mesograzers and nutrient levels on induction of defenses in several Brazilian macroalgae. Mar Ecol Prog Ser. 2004;283:113-25.

70. Gerwick WH, Fenical W. Ichthyotoxic and cytotoxic metabolites of the tropical brown alga Stypopodium zonale (Lamouroux) Papenfuss. J Org Chem. 1981:46:22-7.

71. Hay ME, Fenical W, Gustafson K. Chemical defense against diverse coralreef herbivores. Ecology. 1987;68(6):1581-91.

72. Cetrulo GL, Hay ME. Activated chemical defenses in tropical versus temperate seaweeds. Mar Ecol Prog Ser. 2000;207:243-53. 